\title{
What are the new active vaccine recommendations in the Canadian Immunization Guide?
}

\author{
Warshawsky $\mathrm{B}^{1}$ and Gemmill I ${ }^{2}$ \\ on behalf of the National Advisory Committee on Immunization (NACl)*
}

1 NACI Chair, London, Ontario

$2 \mathrm{NACl}$ Vice-Chair, Kingston, Ontario

* Correspondence to: althea.house@phac-aspc.gc.ca

\section{Introduction}

The scientific advisory body on immunization for the Public Health Agency of Canada is the National Advisory Committee on Immunization (NACl), which develops recommendations for the use of vaccines for Canadians (1). These recommendations and other immunization information are published in the Canadian Immunization Guide (the Guide).

Since the first edition in 1979, the Guide has been a trusted, reader-friendly summary of information that has been used by health care providers to give advice and vaccinations to their patients, and by policy-makers for the delivery of vaccination programs. The document consists of five parts, covering key immunization information, vaccine safety, special populations, active vaccines, and passive immunization agents. Since the 2006 edition, the Guide has undergone extensive revisions and is now published online in an electronic format (2). The objective of this article is to provide some highlights of updates made to Part 4 on Active Vaccines up to February 28, 2014.

\section{Approach}

In revising the Active Vaccine chapters of the Guide, NACI reviewed literature regarding new products, changes in indication, evolving science and practices, as well as national and international recommendations released since 2006. In addition NACl consulted external expertise as necessary.

\section{Summary of updates and additions to Part 4 (Active Vaccines)}

Several new vaccines have been produced since 2006, including vaccines against herpes zoster, human papillomavirus, and rotavirus. Additionally, indications and recommendations have been revised for other vaccines.

Table 1 provides an overview of key changes and additions up to February 28, 2014. As with any therapy, it is most prudent to check the most recent prescribing information prior to use. 
Table 1: Highlights of key changes to active vaccine recommendations in the Canadian Immunization Guide

\begin{tabular}{|c|c|}
\hline Active vaccine & New NACI recommendation \\
\hline BCG & $\begin{array}{l}\text { Revised recommendation regarding when a TB skin test should be given before } \\
\text { administering BCG vaccine to children }<6 \text { months of age }\end{array}$ \\
\hline $\begin{array}{l}\text { Haemophilus influenzae } \\
\text { type b }\end{array}$ & $\begin{array}{l}\text { One dose is recommended regardless of past immunization for those } 5 \text { years of age or } \\
\text { older with the following high-risk conditions: } \\
\text { - Anatomic or functional asplenia (including sickle cell disease) } \\
\text { - Cochlear implants } \\
\text { - } \text { - HIV } \\
\text { - Malignant hematologic disorders } \\
\text { - Transplant candidates/recipients (see Guide for details - three doses } \\
\text { recommended post-hematopoietic stem cell transplant) }\end{array}$ \\
\hline Hepatitis A & $\begin{array}{l}\text { Vaccination recommended for family and close contacts of children adopted from } \\
\text { hepatitis A endemic countries. }\end{array}$ \\
\hline Hepatitis B & 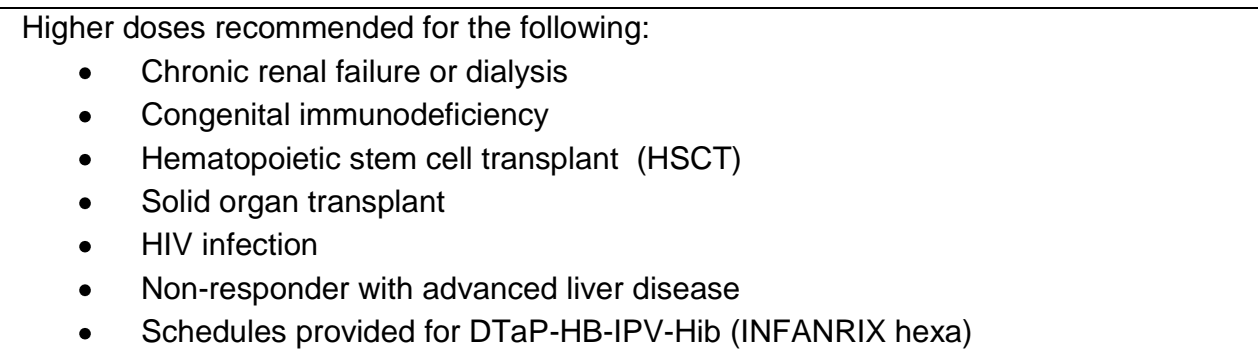 \\
\hline Herpes zoster & $\begin{array}{l}\text { New chapter: Live attenuated vaccine was authorized for the prevention of shingles, } \\
\text { August } 2008 . \\
\text { - Recommended for individuals } 60 \text { years of age and older, and can be considered } \\
\text { for those } 50 \text { to } 59 \text { years of age. } \\
\text { - As it is a live vaccine, it is contraindicated in people with immunocompromising } \\
\text { conditions and people taking immunocompromising drugs, with some exceptions } \\
\text { as outlined in the Guide. } \\
\text { - Expert opinion recommends waiting at least one year from a previous episode of } \\
\text { shingles before receiving the herpes zoster vaccine. } \\
\text { Re-occurrence of herpes zoster ophthalmicus after vaccination (in persons with } \\
\text { previous herpes zoster ophthalmicus) has been reported in several cases world- } \\
\text { wide. The Guide contains management and patient counseling advice. } \\
\text { In contrast to previous recommendations, the herpes zoster vaccine and } \\
\text { pneumococcal vaccines can be co-administered. }\end{array}$ \\
\hline Human papillomavirus & $\begin{array}{l}\text { New chapter: Since 2006, two human papillomavirus (HPV) vaccines have been } \\
\text { authorized for use that protect against four (HPV-4) and two (HPV-2) types of HPV. } \\
\text { - Women: HPV-4 or HPV-2 is recommended for 9-26-year-olds; consider in those } \\
27 \text { years and older with ongoing risk of exposure. } \\
\text { - Men: HPV-4 is recommended for 9-26-year-olds; consider in } 27 \text { years and older } \\
\text { with ongoing risk; strongly consider for men who have sex with men regardless } \\
\text { of age. }\end{array}$ \\
\hline
\end{tabular}




\begin{tabular}{|c|c|}
\hline Active vaccine & New NACI recommendation \\
\hline Influenza & $\begin{array}{l}\text { - Egg allergy is not a contraindication. } \\
\text { Children: } 0.5 \mathrm{~mL} \text { dose is recommended for children when the intramuscular } \\
\text { products are used; live attenuated intranasal vaccine is preferentially } \\
\text { recommended for some age groups; see Guide for details. } \\
\text { For up-to-date information on influenza immunization, please review the most recent } \\
\text { version of the annual influenza statement. }\end{array}$ \\
\hline Measles mumps rubella & $\begin{array}{l}\text { - Chapters clarify who is considered immune, including health care workers, } \\
\text { military personnel, students in post-secondary educational settings, and } \\
\text { travellers. } \\
\text { Health care workers and military personnel require two doses of measles and } \\
\text { mumps vaccine, regardless of year of birth, to be considered immune. }\end{array}$ \\
\hline Meningococcal & 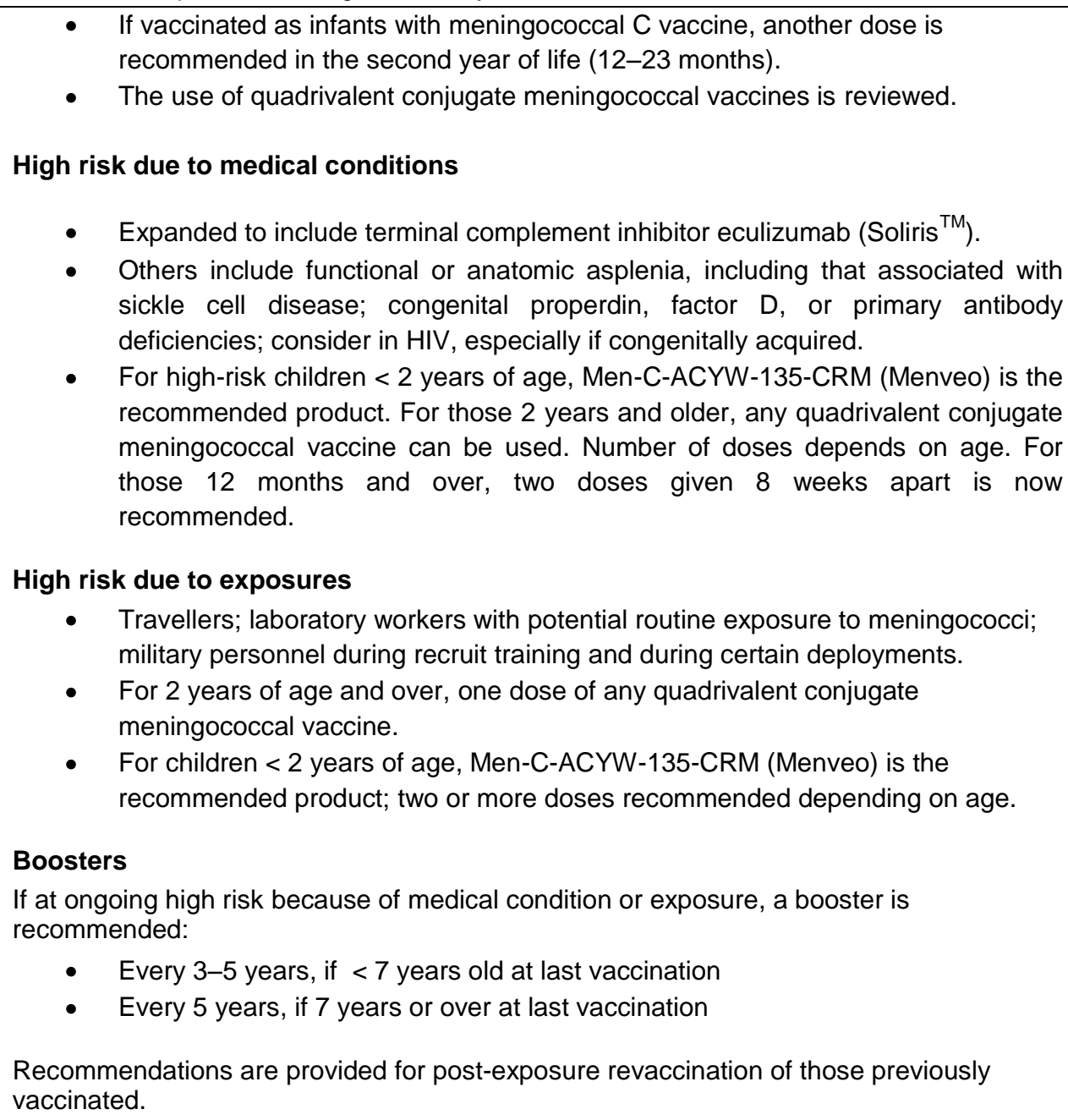 \\
\hline
\end{tabular}




\begin{tabular}{|c|c|}
\hline Active vaccine & New NACI recommendation \\
\hline Pertussis & $\begin{array}{l}\text { Preschool booster at 4-6 years of age } \\
\text { - Either DTaP-IPV or Tdap-IPV can be used. } \\
\text { Adult dose } \\
\text { - One dose of pertussis-containing vaccine (Tdap) if not previously vaccinated in } \\
\text { adulthood. } \\
\text { - Tdap can be given after previous Td without delay. } \\
\text { Pregnancy } \\
\text { - One dose of Tdap can be offered to pregnant women ( } 26 \text { weeks' gestation or } \\
\text { - over) who have not previously been vaccinated against pertussis in adulthood. } \\
\text { In special circumstances, e.g. regional outbreaks, Tdap may be offered to } \\
\text { pregnant women ( } 26 \text { weeks' gestation or over) irrespective of previous } \\
\text { immunization. }\end{array}$ \\
\hline Pneumococcal & $\begin{array}{l}\text { Chapter includes updated vaccination schedules and recommendations for the use of } \\
\text { Pneu-C-13 (Prevnar }{ }^{\Theta} 13 \text { ). } \\
\text { Pneu-C-13 is recommended for the following: } \\
\text { - Children }<59 \text { months of age who have never received conjugate pneumococcal } \\
\text { vaccine } \\
\text { - High-risk children }<18 \text { years of age who have never received Pneu-C-13 } \\
\text { Number of doses is dependent on age; those } 2 \text { years and over receive only one dose, } \\
\text { except for those who are post-HSCT, for whom a three-dose schedule is recommended. } \\
\text { Polysaccharide vaccine is also recommended for high-risk children } 2 \text { years of age and } \\
\text { over after receipt of PCV } 13 \text {. } \\
\text { Definitions of high-risk and immunocompromising conditions are provided in the Guide. } \\
\text { Catch-up schedules for those }<59 \text { months of age who have received another conjugate } \\
\text { pneumococcal vaccine, but not Prevnar } 13 \text {, are provided in the Guide. }\end{array}$ \\
\hline Poliomyelitis & $\begin{array}{l}\text { - } \quad \text { Adults should be vaccinated if not previously vaccinated. } \\
\text { Priority for people at risk, such as travellers possibly exposed to someone } \\
\text { excreting polio virus; others should be vaccinated when they need a primary } \\
\text { tetanus series or tetanus booster. }\end{array}$ \\
\hline Rabies & $\begin{array}{l}\text { A four-dose schedule (instead of five) is recommended for post-exposure } \\
\text { management for those who are not immunocompromised and not taking anti- } \\
\text { malarial prophylaxis. Give on day } 0 \text { (first dose), } 3,7 \text {, and } 14 \text {. } \\
\text { - If immunocompromised or taking anti-malarial prophylaxis, give five doses on } \\
\text { day } 0 \text { (first dose), } 3,7,14 \text {, and } 28 \text {. } \\
\text { Post-exposure management based on risk assessment. Factors to consider } \\
\text { provided in the Guide. }\end{array}$ \\
\hline
\end{tabular}




\begin{tabular}{|c|c|}
\hline Active vaccine & New NACI recommendation \\
\hline Rotavirus & $\begin{array}{l}\text { New chapter: Since mid-2006, two live, oral rotavirus vaccines have been authorized for } \\
\text { use; one requires three doses and the other requires two doses. } \\
\text { - For both products, the first dose should be given before } 14 \text { weeks and } 6 \text { days of } \\
\text { age and the last dose before } 8 \text { months of age. } \\
\text { Intussusception is recognized as a rare adverse event following rotavirus } \\
\text { vaccination. }\end{array}$ \\
\hline Travel vaccines & $\begin{array}{l}\text { Japanese encephalitis vaccine } \\
\text { - New inactivated vaccine (Ixiaro) for } 18 \text { years and over. } \\
\text { Yellow fever } \\
\text { - Classification of countries into risk levels. } \\
\text { - Probable transmission during breastfeeding reported. } \\
\text { Tick-borne encephalitis } \\
\text { - New chapter has been added to the Guide. }\end{array}$ \\
\hline Varicella & $\begin{array}{l}\text { - Two doses recommended for susceptible individuals of all ages. } \\
\text { - Use of MMRV vaccine outlined in the chapter. } \\
\text { - Chapter outlines who is considered immune. Adults } 50 \text { years of age and older } \\
\text { can be considered immune unless known to be susceptible on the basis of } \\
\text { previous laboratory testing; health care providers and those born in or after } 2004 \\
\text { require a health care provider diagnosis of chickenpox, two documented doses } \\
\text { of varicella vaccine or laboratory- confirmed disease, or immunity (this is } \\
\text { currently under review by NACI). } \\
\text { - Minimum intervals between varicella-containing vaccines identified. }\end{array}$ \\
\hline
\end{tabular}

\section{Conclusion}

The Canadian Immunization Guide is a trusted and reliable resource for immunizers in Canada. Part 4 of the Guide on active vaccines has been updated to incorporate new science and practices and reflects recent recommendations by $\mathrm{NACl}$. NACl and the Public Health Agency of Canada are committed to providing this information in an easily accessible, reader-friendly format through timely and ongoing updates of the on-line version.

\section{References}

(1) National Advisory Committee on Immunization. 2014; http://www.phac-aspc.gc.ca/naci-ccni

(2) National Advisory Committee on Immunization. Part 4: Active vaccines. In: Canadian Immunization Guide. 2014; http://www.phac-aspc.gc.ca/publicat/cig-gci/

\section{Acknowledgements}

The authors would like to thank the extremely dedicated members of NACI who devoted considerable time and effort to revising the Guide as well as the excellent Public Health Agency of Canada staff who have supported the revision process.

\section{Conflict of Interest}

No conflicts of interest to declare. 